\title{
IMPLEMENTASI WEB ENGINEERING METHOD PENGELOLAAN PENDISTRIBUSIAN OBAT GUDANG FARMASI DINAS KESEHATAN PAGAR ALAM
}

\author{
Inda Anggraini ${ }^{1^{*}}$, Debi Gusmaliza ${ }^{2}$ \\ Program Studi Teknik Informatika, Sekolah Tinggi Teknologi Pagaralam ${ }^{1,2}$ \\ e-mail: inda.anggraini@sttpagaralam.ac.id ${ }^{1}$, debi.gusmaliza@sttpagaralam.ac.id ${ }^{2}$
}

\begin{abstract}
Abstrak
Pengelolaan pendistribusian obat di gudang farmasi dilakukan dengan menggunakan aplikasi office dan excel. Puskesmas yang ada di pagar alam mengajukan lampiran daftar permintaan obat lalu pihak gudang farmasi mengevaluasi permintaan obat dari ketujuh puskesmas tersebut untuk kemudian dilakukan pengecekan ketersediaan obat. Pengelolaan yang masih dilakukan dengan metode sederhana memberikan beban kerja yang ditanggung cukup berat. Penelitian ini bertujuan untuk merancang dan mengimplementasikan Pengelolaan Pendistribusian obat berbasis web yang dapat membantu pegawai gudang farmasi dalam mengelola data obat dan juga mempermudah dalam pembuatan laporan distribusi obat. Metode pengembangan sistem yang digunakan dalam merancang pengelolaan pendistribusian obat adalah metode Web Engineering yang terdiri dari 5 tahapan yaitu Customer Communication, Planning, Modeling, Construction, Deployment. Sedangkan tools atau aplikasi pembantu yang digunakan untuk membuat perancangan dan implementasi pengelolaan pendistribusian obat ini adalah Axure dan UML ( Unified Modeling Languange). Bahasa pemrograman menggunakan HTML, PHP, database MySQL dan Farmework codeigniter dan pengujian sistem menggunakan metode Blackbox Testing dengan hasil pengujian valid atau not valid. Hasil penelitian ini berupa sistem pengelolaan pendistribusian obat pada gudang farmasi Dinas Kesehatan Kota Pagar Alam yang dapat membantu memudahkan pihak gudng farmasi dalam mengelola pendistribusian obat yang langsung terhubung kedalam tujuh puskesmas yang ada di kota pagar alam.
\end{abstract}

Kata kunci : Web Engineering; PHP; MySql; Codeighniter; Balck Box Testing

\begin{abstract}
Management of drug distribution in pharmacy warehouses is carried out using office applications and excel. The Puskesmas in the natural fence submits an attachment to the drug request list, then the pharmacy warehouse evaluates the drug requests from the seven health centers to then check the availability of drugs. Management which is still carried out with a simple method gives a heavy workload. This study aims to design and implement a web-based drug distribution management that can help pharmacy warehouse employees manage drug data and also facilitate the preparation of drug distribution reports. The system development method used in designing drug distribution management is the Web Engineering method which consists of 5 stages, namely Customer Communication, Planning, Modeling, Construction, Deployment. Meanwhile, the supporting tools or applications used to design and implement this drug distribution management are Axure and UML (Unified Modeling Language). Programming language using HTML, PHP, MySQL database and Farmework codeigniter and system testing using the Blackbox Testing method with valid or not valid test results. The results of this study are in the form of a drug distribution management system at the pharmacy warehouse of the Pagar Alam City Health Office which can help facilitate the pharmacy warehouse in managing drug distribution which is directly connected to seven health centers in the city of Fence
\end{abstract}

Keywords : Web Engineering; PHP; MySQL; Codeighniter; Black Box Testing 


\section{PENDAHULUAN}

Perkembangan teknologi terutama dalam bidang kesehatan sangat berperan penting di karenakan dengan adanya teknologi dapat mempermudah pekerjaan yang di lakukan tanpa terhalang jarak dan waktu, teknologi di dunia kesehatan merupakan salah satu upaya agar dapat memperlancar suatu proses yang dilakukan untuk meningkatkan kualitas pelayanan kesehatan dimana sangat membantu, terutama dalam pengelolaan distribusi obat pada setiap kota. [1]

Pendistribusian obat merupakan suatu rangkaian dalam rangka menyalurkan sediaan farmasi, alat kesehatan, BHP Medis dari tempat penyimpanan sampai kepada unit pelayanan atau pasien dengan tetap menjamin mutu, stabilitas, jenis, jumlah, ketepatan waktu [2]

Menurut penelitian [3] dengan judul perancangan sistem informasi pendistribusian obat dan alat kontrasepsi di kantor badan keluarga dan emberdayaan perempuan kota lubuk linggau berbasis web mobile, menghasilkan sistem informasi yang dapat membantu dalam pemesanan obat an alat kontrasepsi serta membuat pendistribusian menjadi lebih efektif dibandingkan dengan belum adanya sistem sebelumnya yang dirancang dengan menggunakan pendekatan terstruktur dengan menggunakan beberapa tools.

Dalam mengelola pendistribusian obat ke tujuh puskesmas yang ada di kota pagar alam, gudang farmasi harus mengelola data pendistribusian dengan baik. Pendistribusian obat yang dilakukan oleh gudang farmasi dinas kesehatan kota Pagar Alam yaitu dengan adanya permintaan obat dari 7 puskesmas serta melampirkan daftar permintaan obat lalu pihak gudang farmasi melakukan evaluasi terhadap daftar permintaan obat dari 7 puskesmas tersebut, gudang farmasi dalam mengelola data tersebut mempunyai kelemahan, diantaranya masalah kemudahan, kecepatan dan keakuratan. Pengelolaan data yang masih dilakukan dengan metode sederhana memberikan beban kerja yang ditanggung pegawai gudang farmasi cukup berat, selain itu data persediaan obat di gudang farmasi dan Puskesmas selalu berubah tergantung aktifitasnya. Perhitugan persediaannya masih di lakukan masing-masing pihak, padahal pada aktifitas pendistribusian obat dari gudang farmasi ke Puskesmas data yang di proses sebenarya sama, tetapi dengan metode seperti ini terdapat kemungkinan terjadinya kesalahan manusia, sehingga data yang di proses tidak sama.

Tujuan dari penelitian ini adalah untuk meringankan beban kerja yang ditanggung oleh pegawai gudang farmasi dalam mengelolah data pendistribusian obat serta memudahkan dalam mengarsipkan dan menghitung setiap perubahan di yang terjadi dalam setiap aktifitas. Dengan system ini juga nantinya dapat mempermudah pihak puskesmas di kota pagar alam dalam memantau persediaan obat di dalam gudang farmasi kota pagar alam. Sistem ini dibangun dengan menggunakan metode web engineering yang terdiri dari customer communication, planning, modeling, construction dan deployment.

\section{TINJAUAN PUSTAKA}

\subsection{Implementasi}

Implementasi merupakan suatu proses yang dinamis, dimana pelaksana kebijakan melakukan suatu aktivitas atau kegiatan, sehingga pada akhirnya akan mendapatkan suatu hasil yang sesuai dengan tujuan atau sasaran kebijakan itu sendiri.[4]

Implementasi dapat juga diartikan sebagai sebuah tindakan atau pelaksanaan dari rencana yang telah disusun terperinci. Implementasi biasanya dilaksanakan setelah rencana sudah dinyatakan fix.[5] 


\subsection{Web Engineering}

Web engineering adalah metode yang digunakan untuk membuat aplikasi web berkualitas tinggi. Proses dari web enginerring sendiri dimulai dengan penentuan cara pemecahan masalah oleh web aplikasi.[6]

Web engineering memiliki 5 tahapan yaitu: customer communication, planning, modeling, construction dan deployment.

\subsection{Pengelolaan}

Pengelolaan (processing) merupakan proses pengelolaan berupa data yang diolah melalui suatu model menjadi informasi, penerima kemudian menerima informasi tersebut, Data tersebut akan ditangkap sebagai Input, diproses kembali lewat suatu model dan seterusnya membentuk suatu siklus, Siklus ini disebut juga dengan siklus pengolahan data. [7]

Pengelolaan adalah teknik khusus yang dapat dirangkum dalam proses digitalisasi, penyimpanan dan pengaksesan kembali dalam bentuk dokumen. [8]

\subsection{Distribusi}

Ditribusi adalah salah satu aspek dari pemasaran, distribusi juga dapat diartikan sebagai kegiatan pemasaran yang berusaha memperlancar dan mempermudah penyampaian barang dan jasa dari produsen kepada konsumen, sehingga penggunaannya sesuai dengan yang diperlukan (jenis, jumlah, harga, tempat, dan saat dibutuhkan) [9].

Pendistribusian merupakan kegiatan pemasaran yang mempermudah penyampaian produk dan jasa dari produsen ke konsumen sehingga penggunaan sesuai (jenis, jumlah, harga, tempat dan saat) dengan yang diperlukan [10].

\subsection{Penelitian Terdahulu}

Berdasarkan penelitian terdahulu dengan judul "Perancangan Sistem Informasi Distribusi Obat Pasien Rawat Inap )Studi Kasus : RSUD Cideres Kadipaten)" dengan hasil sistem yang dibangun dapat mengatasi kesalahan distribusi obat yang kurang tepat sasaran kepada pasien. Dengan mengatasi sistem ini juga melakukan pengelolaan distribusi yang lebih cepat, mudah, dan aman jika dibandingkan dengan cara konvensional.

Penelitian yang dilakukan M Putra, Fadli, \& Saleh yang berjudul "Rancang Bangun Sistem Pengolah Obat Menggunakan Model Spiral" dengan hasil sistem ini dapat mempermudah bagian gudang dan apotek dalam pembuatan laporan pemakaian dan permintaan obat yang merupakan kegiatan rutin yang wajib dibuat dan dilaporkan oleh masing-masing bagian kepada dinas kesehatan. Penelitian ini menggunakan model spiral, sedangkan metode yang digunakan penulis dalam membangun sistem ini yaitu metode web engineering.

\section{METODOLOGI PENELITIAN}

Penelitian ini dimulai dengan analisis mulai dari analisis data sampai ke system yang sedang berjalan pada pengolahan data obat di dinas kesehatan. Kemudian dilanjutkan dengan perencanaan pembangunan system, pemodelan dari system tersebut, dilanjutkan dengan pengerjaan atau pengkodingan hingga pengujian system yang sudah jadi. Tahapan dari penelitian ini bias dilihat pada gambar berikut. 


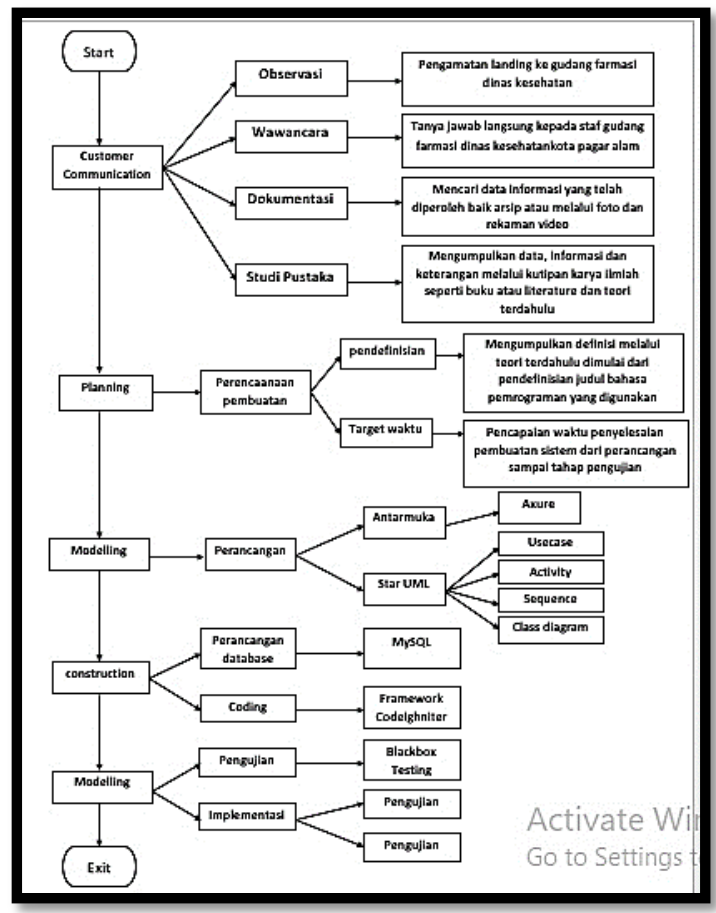

Gambar 1 Kerangka Berpikir

\subsection{Metode Pengumpulan Data}

a. Observasi

Melakukan pengamatan dan terlibat langsung didalam kegitan lapangan pada objek yang akan diteliti dan dibahas serta menggumpulkan data dan informasi sebanyak mungkin yang berhubungan dengan masalah yang akan diteliti.

b. Wawancara

Pengumpulan data dengan melakukan tanya jawab secara langsung kepada staf Gudang Farmasi Dinas Kesehatan Kota Pagar Alam yang mengerti dengan kasus yang sedang diteliti pada gambaran sistem yang ada.

c. Study Pustaka

Mempelajari teori-teori dengan cara mengumpulkan data, informasi dan keterangan melalui kutipan karya ilmiah seperti buku atau literatur yang berhubungan dengan kasus yang sedang di teliti.

\subsection{Metode Pengembangan Sistem}

Metode yang digunakan dalam penelitian ini adalah metode web engineering atau web engineering method [6]. Metode ini terdiri dari 5 tahapan yaitu:

a. customer communication

Pada tahapan ini dilakukan komunikasi dengan staf gudang farmasi dan pengguna sistem lainnya (User) untuk mengetahui apa saja yang di inginkan oleh pengguna sistem yaitu dari sisi Input dan output yang akan dihasilkan serta fasilitas apa saja yang harus ada pada sistem ini nantinya.

b. Planning

Pada tahap ini merupakan perencanaan semua kebutuhan yang diperlukan dalam pengembangan sistem ini agar lancar, yaitu mengumpulkan teori-teori terhadulu di mulai dari teori judul sampai bahasa pemrograman yang akan digunakan. Serta menentukan pencapaian waktu penyelesaian pembuatan sistem dari perancangan sampai tahap pengujian sistem.

c. Modeling

Pada tahap ini, dilakukan analisa terhadap sistem yang berjalan, menganalisa kebutuhan sistem yang akan dikembangkan, serta membuat rancangan (design) struktur tabel basis data dan rancangan struktur menu serta tampilan halaman dengan menggunakan aplikasi pendukung Axure dan Star UML.

d. construction

Pada tahap Construction ini, peneliti membangun pengelolaan pendistribusian data obat pada gudang farmasi dinas kesehatan Kota Pagar Alam dengan menggukan database MySQL dan bahasa pemograman framework codeigniter.

e. deployment.

Web app dikonfigurasikan untuk lingkup operasionalnya, diluncurkan 
pada pengguna akhir dan kemudian adanya tahap evaluasi.

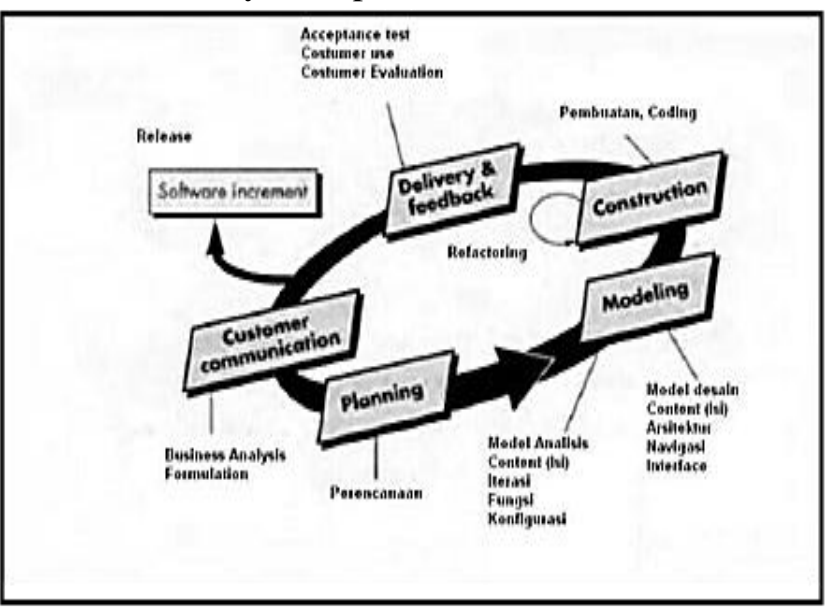

Gambar 1 Model Web Engineering Sumber. Rosa \& M.Shalahuddin (Rekayasa Perangkat Lunak, Bandung:2016)

\subsection{Pengujian Black Box Testing}

Metode blacbox testing merupakan metode yang digunakan untuk menguji perangkat lunak dari segi spesifikasi fungsional tanpa menguji desain dank ode program, metode ini ditujukan untuk menguji fungsi, masukan dan keluaran dari perangkat lunak atau sistem sesuai dengan kebutuhan. [11].

\section{HASIL DAN PEMBAHASAN}

\subsection{Implementasi Sistem}

1. Implementasi Halaman Admin

Halaman ini merupakan halaman utama atau halaman awal yang ditampilkan pada saat admin berhasil masuk ke dalam system. Pada halaman ini admin dapat mengelola semua yang ada dalam sistem, seperti mengelola data user dari masingmasing puskesmas, data pemasok, data permintaan obat, serta mengelola laporan. Implementasi halaman admin dapat dilihat pada gambar berikut.

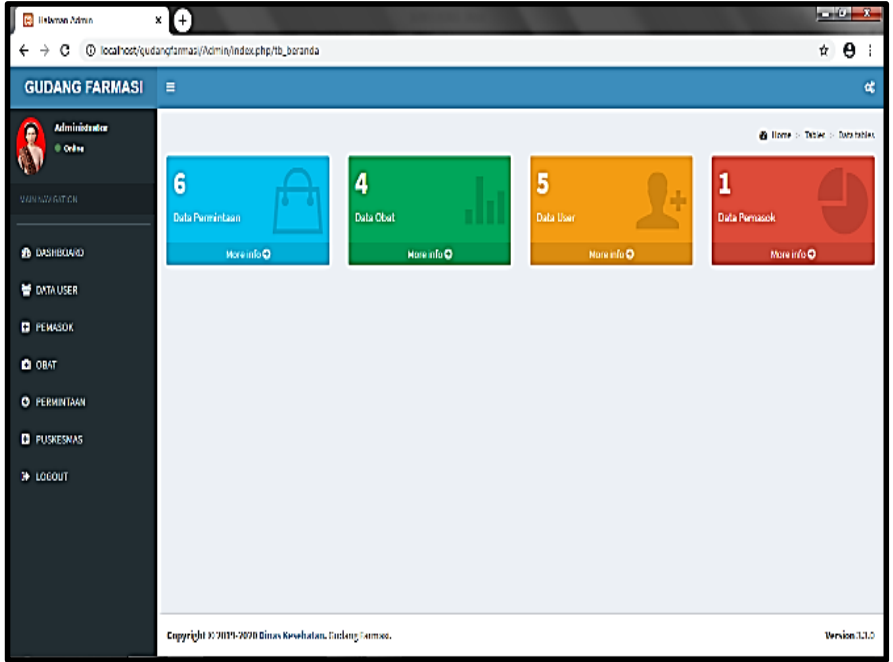

Gambar 2 Implementasi halaman dashboard admin

Sumber.Dinas Kesehatan kota Pagar Alam

2. Implementasi Halaman kelola data uskesmas

Pada halaman ini admin dapat menginput, mengedit, mengubah serta mendaftaran nama puskesmas baru yang belum terdaftar di dalam sistem. Didalam halaman ini juga admin dapat melihat kelenngkapan data puskesmas yang akan diakses oleh masing-masing admin di puskesmas yang bersangkutan.

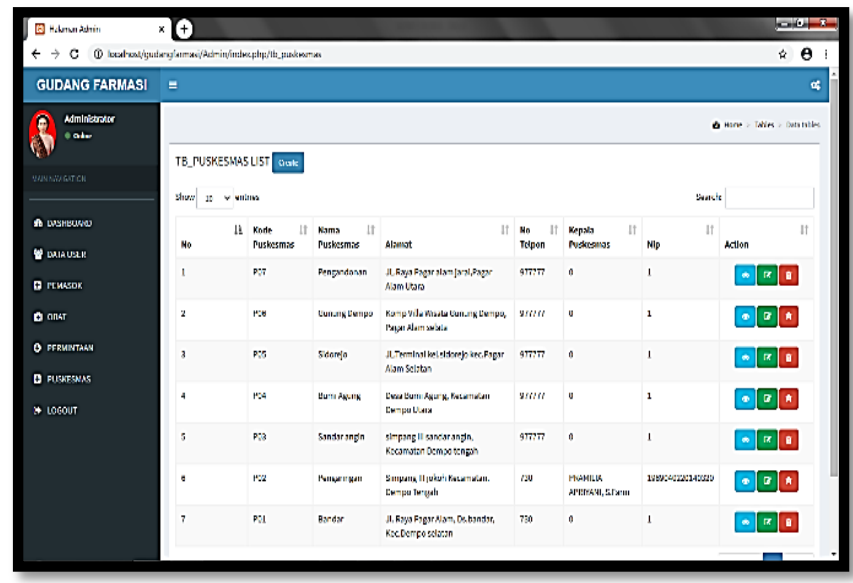

Gambar 3 Implementasi halaman kelola data puskesmas

Sumber.Dinas Kesehatan kota Pagar Alam 
3. Implementasi Halaman Kelola Data Obat

Halaman ini merupakan halaman data obat, admin dapat menambahkan data obat berupa nama, jenis serta jumlah stok yang ada di gudang farmasi. Dari sini juga user nantinya dapat melihat ketersediaan obat.

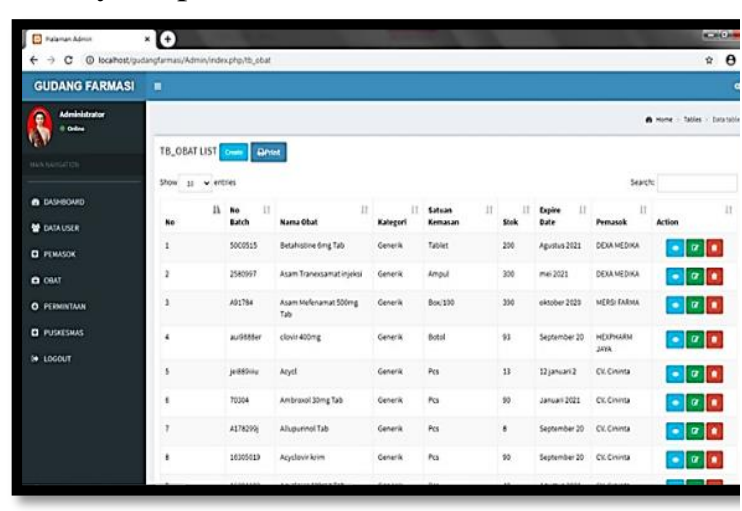

Gambar 4 Implementasi halaman kelola obat

Sumber.Dinas Kesehatan kota Pagar Alam

4. Implementasi Halaman Permintaan User

Halaman ini merupaka halaman permintaan yang diinputkan user dari puskesmas yang bersangkutan. Pada halaman ini user dapat menginputkan atau menambahkan data permintaan obat dan juga dapat mencetak data permintaan obat untuk diarsipkan dan dilaporan ke atasan puskesmas masing-masing.

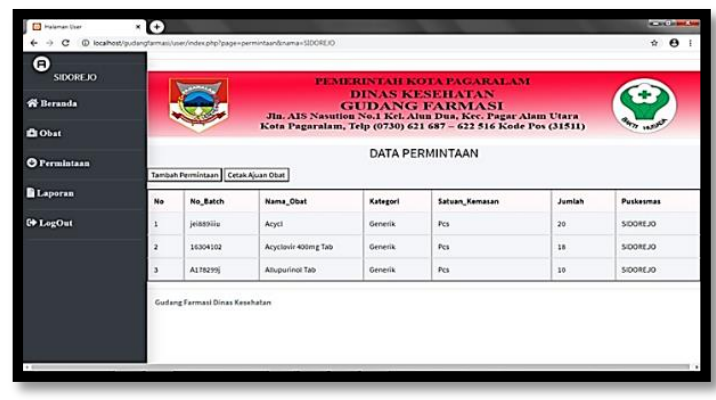

Gambar 5 Implementasi halaman permintaan user

Sumber.Dinas Kesehatan kota Pagar Alam

\subsection{Hasil Pengujian Dengan Blackbox Testing}

Setelah system diimplementasikan maka tahap selanjutnya adalah pengujian untuk mengetahui dan memastikan bahwa system yang dibuat tidak terdapat kesalahan atau eror dari seluruh fungsional system. Pengujian yang dilakukan yaitu :

a. Fungsi view, input data, print dan kelola data

b. User interface

Tabel 1 Tabel hasil pengujian dengan blackbox testing

\begin{tabular}{|c|c|c|c|c|}
\hline $\begin{array}{l}\mathbf{N} \\
\mathbf{0}\end{array}$ & $\begin{array}{c}\text { Skenario } \\
\text { Pengujian }\end{array}$ & $\begin{array}{c}\text { Hasil Yang } \\
\text { Diharapka } \\
\text { n } \\
\end{array}$ & $\begin{array}{c}\text { Hasil } \\
\text { Penguj } \\
\text { ian }\end{array}$ & $\begin{array}{c}\text { Kesimpu } \\
\text { lan }\end{array}$ \\
\hline 1 & $\begin{array}{l}\text { Mengosong } \\
\text { kan } \\
\text { username } \\
\text { dan } \\
\text { password } \\
\text { pada form } \\
\text { login lalu } \\
\text { klik login }\end{array}$ & $\begin{array}{l}\text { Sistem akan } \\
\text { menolak } \\
\text { dan } \\
\text { menampilk } \\
\text { an } \\
\text { notifikasi } \\
\text { dan akan } \\
\text { kembali ke } \\
\text { form login } \\
\text { lagi }\end{array}$ & $\begin{array}{l}\text { Sistem } \\
\text { menola } \\
\mathrm{k} \mathrm{dan} \\
\text { kembal } \\
\mathrm{i} \text { ke } \\
\text { menu } \\
\text { login }\end{array}$ & Succses \\
\hline 2 & $\begin{array}{l}\text { Menginput } \\
\text { kan } \\
\text { username } \\
\text { dan } \\
\text { password } \\
\text { dengan } \\
\text { benar lalu } \\
\text { klik login }\end{array}$ & $\begin{array}{l}\text { Sistem akan } \\
\text { menerima } \\
\text { dan } \\
\text { memvalidas } \\
\text { i data dan } \\
\text { mengarahk } \\
\text { an ke } \\
\text { halaman } \\
\text { dashboard } \\
\text { administrat } \\
\text { or }\end{array}$ & $\begin{array}{l}\text { Sistem } \\
\text { memva } \\
\text { lidasi } \\
\text { data } \\
\text { dan } \\
\text { menuju } \\
\text { ke } \\
\text { dashbo } \\
\text { ard } \\
\text { admin }\end{array}$ & Success \\
\hline 3 & $\begin{array}{l}\text { Input data } \\
\text { user untuk } \\
\text { akses dari } \\
\text { masing- } \\
\text { masing } \\
\text { puskesmas }\end{array}$ & $\begin{array}{l}\text { Sistem } \\
\text { berhasil } \\
\text { menyimpan } \\
\text { data jika } \\
\text { data sudah } \\
\text { lengkap }\end{array}$ & $\begin{array}{l}\text { Sistem } \\
\text { menyi } \\
\text { mpan } \\
\text { data } \\
\text { yang } \\
\text { diinput }\end{array}$ & Success \\
\hline 4 & $\begin{array}{l}\text { Input data } \\
\text { pemasok } \\
\text { sesuai data } \\
\text { yang } \\
\text { dibutuhkan }\end{array}$ & $\begin{array}{l}\text { Sistem } \\
\text { berhasil } \\
\text { menyimpan } \\
\text { data yang } \\
\text { diinputkan }\end{array}$ & $\begin{array}{l}\text { Sistem } \\
\text { menyi } \\
\text { mpan } \\
\text { data }\end{array}$ & Success \\
\hline 5 & $\begin{array}{l}\text { Input data } \\
\text { ketersediaa } \\
\mathrm{n} \text { obat dan } \\
\text { pengelolaan } \\
\text { ketersediaa } \\
\mathrm{n}\end{array}$ & $\begin{array}{l}\text { Sistem } \\
\text { berhasil } \\
\text { mengelola } \\
\text { ketersediaa } \\
\mathrm{n}\end{array}$ & $\begin{array}{l}\text { Sistem } \\
\text { mengel } \\
\text { ola } \\
\text { keterse } \\
\text { diaan }\end{array}$ & Succsess \\
\hline 6 & $\begin{array}{l}\text { User } \\
\text { mengajuka } \\
\mathrm{n} \\
\text { permintaan } \\
\text { obat dan } \\
\text { mengecek } \\
\text { ketersediaa } \\
\mathrm{n}\end{array}$ & $\begin{array}{l}\text { Sistem } \\
\text { berhasil } \\
\text { menampilk } \\
\text { an data } \\
\text { ketersediaa } \\
\text { n obat }\end{array}$ & $\begin{array}{l}\text { Sistem } \\
\text { berhasi } \\
1 \\
\text { menyi } \\
\text { mpan } \\
\text { data } \\
\text { permin } \\
\text { taan }\end{array}$ & Succsess \\
\hline 7 & $\begin{array}{l}\text { Admin } \\
\text { mencetak } \\
\text { data }\end{array}$ & $\begin{array}{l}\text { Sistem } \\
\text { menampilk } \\
\text { an data }\end{array}$ & $\begin{array}{l}\text { Sistem } \\
\text { mengar } \\
\text { ahkan }\end{array}$ & Succsess \\
\hline
\end{tabular}




\begin{tabular}{|c|c|c|c|c|}
\hline & $\begin{array}{l}\text { permintaan } \\
\text { obat dari } \\
\text { setiap } \\
\text { puskesmas }\end{array}$ & $\begin{array}{l}\text { berdasarkan } \\
\text { tempat } \\
\text { masing- } \\
\text { masing }\end{array}$ & $\begin{array}{l}\text { admin } \\
\text { untuk } \\
\text { mencet } \\
\text { ak }\end{array}$ & \\
\hline 8 & $\begin{array}{l}\text { User } \\
\text { menginputk } \\
\text { an } \\
\text { username } \\
\text { dan pass } \\
\text { melalui } \\
\text { form login } \\
\text { dengan } \\
\text { benar }\end{array}$ & $\begin{array}{l}\text { Sistem akan } \\
\text { memvalidas } \\
\text { i data dan } \\
\text { mengarahk } \\
\text { an ke } \\
\text { dashboard } \\
\text { admin dari } \\
\text { puskesmas } \\
\text { masing- } \\
\text { masing }\end{array}$ & $\begin{array}{l}\text { Sistem } \\
\text { memva } \\
\text { lidasi } \\
\text { data } \\
\text { dan } \\
\text { masuk } \\
\text { ke } \\
\text { dasghb } \\
\text { ord } \\
\text { user }\end{array}$ & Succsess \\
\hline 9 & $\begin{array}{l}\text { User } \\
\text { mengecek } \\
\text { ketersediaa } \\
\mathrm{n} \mathrm{obat} \mathrm{di} \\
\text { gudang } \\
\text { melalui } \\
\text { sistem } \\
\end{array}$ & $\begin{array}{l}\text { Sistem akan } \\
\text { menampilk } \\
\text { an data } \\
\text { ketersediaa } \\
\text { n obat }\end{array}$ & $\begin{array}{l}\text { Berhasi } \\
1 \\
\text { nemam } \\
\text { pilkan }\end{array}$ & Succsess \\
\hline $\begin{array}{l}1 \\
0\end{array}$ & $\begin{array}{l}\text { User } \\
\text { mengisi for } \\
\text { permintaan } \\
\text { obat untuk } \\
\text { diajukan ke } \\
\text { sistem } \\
\text { pusat di } \\
\text { gudang }\end{array}$ & $\begin{array}{l}\text { Sistem akan } \\
\text { menyimpan } \\
\text { data } \\
\text { permintaan }\end{array}$ & $\begin{array}{l}\text { Sistem } \\
\text { menyi } \\
\text { mpan } \\
\text { data }\end{array}$ & Sucsess \\
\hline $\begin{array}{l}1 \\
1\end{array}$ & $\begin{array}{l}\text { Admin } \\
\text { mengola } \\
\text { data } \\
\text { permintaan } \\
\text { dan } \\
\text { memproses } \\
\text { permintaan }\end{array}$ & $\begin{array}{l}\text { Sistem akan } \\
\text { mengupdat } \\
\mathrm{e} \\
\text { ketersediaa } \\
\mathrm{n} \quad \text { setelah } \\
\text { proses } \\
\text { kirim obat } \\
\text { ke } \\
\text { permintaan } \\
\text { user }\end{array}$ & $\begin{array}{l}\text { Sistem } \\
\text { berhasi } \\
1 \\
\text { mengol } \\
\text { a data } \\
\text { dan } \\
\text { mengu } \\
\text { pdate } \\
\text { inform } \\
\text { asi }\end{array}$ & Success \\
\hline
\end{tabular}

Sumber.Dinas Kesehatan kota Pagar Alam

\section{KESIMPULAN}

Berdasarkan hasil yang telah didapat setelah penelitian selesai dapat disimpulkan bahwa:

a. Hasil penelitian ini dapat memberikan solusi dari mengenai permasalahan yang terjadi di gudang farmasi dinas kesehatan kota pagar alam dengan 7 puskesmas yang beroperasi didalamnya

b. Informasi mengenai ketersediaan obata dapat diketahui dengan mudah dan cepat

c. Dari hasil pengujian system telah memenuhi syarat untuk diimplementasikan langsung ke gudang farmasi untuk pendistribusian obat

\section{SARAN}

Penelitian ini dapat dijadikan acuan untuk pengembangan kedepan dalam aktifitas pendistribusian obat maupun pengelolaan data-data yang tersedia.

\section{DAFTAR PUSTAKA}

[1] N. Abbas, "Perkembangan Teknologi Di Bidang Produksi Pangan Dan Obat-Obatan Serta HakHak Konsumen," J. Huk. Ius Quia Iustum, vol. 16, no. 3, pp. 423-438, 2009 , doi: 10.20885/iustum.vol16.iss3.art7.

[2] S. H. Febreani and D. Chalidyanto, "Pengelolaan Sediaan Obat Pada Logistik Farmasi Rumah Sakit Umum Tipe B di Jawa Timur," J. Adm. Kesehat. Indones., vol. 4, no. 2, p. 136, 2016, doi: 10.20473/jaki.v4i2.2016.136-145.

[3] D. Irawan, "Perancangan sistem informasi pendistribusian obat dan alat," Jutim, vol. 2, no. 1, pp. 13-22, 2017.

[4] R. P. Bendriyanti and L. N. Zulita, "Implementasi E-Arsip Pada Kanwil Kementerian Agama Provinsi Bengkulu," J. Media Infotama, vol. 8, no. 1, pp. 158-177, 2012, [Online]. Available:

http://jurnal.unived.ac.id/index.php/j $\mathrm{mi} /$ article/view/77.

[5] N. A. Hasibuan et al., "Implementasi Data Mining Untuk Pengaturan Layout," vol. 4, no. 4, pp. 6-11, 2017.

[6] H. Yudiastuti and I. Irwansyah, "Implementasi Metode Web Engineering Dalam Membangun Sistem E-Reservation Pemesanan Kamar Hotel," J. Ilm. Matrik, vol. 21, no. 2, pp. 146-155, 2019, doi: 10.33557/jurnalmatrik.v21i2.568.

[7] A. P. Nugroho and J. T. Informatika, "DATA BENGKEL SECARA 
ELEKTRONIK," vol. 2, no. 1, pp. 54-69, 2017.

[8] Y. Widayanti, "Pengelolaan Perpustakaan Digital," Libr. J. Perpust., vol. 3, no. 1, pp. 125-137, 2015, [Online]. Available: http://journal.stainkudus.ac.id/index. php/Libraria/article/view/1579.

[9] M. A. Putri, Rosmayani, and Rosmita, "Analisis Faktor-Faktor Yang Mempengaruhi Saluran Distribusi Usaha Kecil Menengah (UKM) (Survei Pada Kue Bangkit 'Syempana' Di Kota Pekanbaru)," J. Chem. Inf. Model., vol. 53, no. 9, pp. 1689-1699, 2018, [Online]. Available:

https://journal.uir.ac.id/index.php/va luta/article/view/2586/1460.

[10] V. Motora Daya Adira, "Sistem Informasi Pendistribusian Material Promosi Sparepart Ke Jaringan Dealer Di Pt .Daya Adicipta Motora," FIKI |Jurnal Teknol. Inf. dan Komun., vol. VIII, no. 2, pp. 8189, 2018.

[11] W. N. Cholifah, Y. Yulianingsih, and S. M. Sagita, "Pengujian Black Box Testing pada Aplikasi Action \& Strategy Berbasis Android dengan Teknologi Phonegap," STRING (Satuan Tulisan Ris. dan Inov. Teknol., vol. 3, no. 2, p. 206, 2018, doi: 10.30998/string.v3i2.3048. 